\title{
Gorbachev and Thatcher
}

\author{
Witness Remarks
}

\section{Rodic BRAITHWAITE}

Thatcher played a significant but limited role in East-West relations in the last decade of the Soviet Union. She had her own vision of how East-West relations should be shaped. ${ }^{1}$ She was not prepared to accept the status quo, and she was one of the first Western politicians to give public support for liberal change in Eastern Europe. In the 1980s she played an important role in reopening up communications with the Soviet Union at a time when they were in difficulty. But the serious negotiation of change was conducted not by her, but by the American President and the German Chancellor. $^{2}$

\section{Thatcher comes to power}

In the late 1970s detente between the Soviet Union and the West began to unravel, and tension increased markedly. This was the dominating thought in Thatcher's mind when she became Prime Minister in May 1979. She believed that the balance of power between East and West had been seriously altered by the Soviet military build-up and the failure of the West, and especially Britain, to match it. ${ }^{3}$

1. Sir Rodric Braithwaite is a writer and former British Ambassador in Moscow during the fall of the Soviet Union (1988-1992). His diplomatic career included posts in Jakarta, Warsaw, Moscow, Rome, Brussels (European Union) and Washington and a number of positions at the Foreign and Commonwealth Office. He was Prime Minister's foreign policy adviser and Chairman of the Joint Intelligence Committee (1992/93), was awarded the GCMG in 1994 and knighted in 1988. Braithwaite was a Visiting Fellow at All Souls College, Oxford in 1972-73 and at the Wilson Center in Washington in 2005. Among his publications: Engaging Russia: A Report to the Trilateral Commission, with Robert Blackwill and Akihiko Tanaka (1995); Russia in Europe (1999); Across the Moscow River: The World Turned Upside Down and Moscow 1941: A City and Its People at War (2003); Moscow 1941: A City and its People at War (2006). His forthcoming book: Afgantsy: The Russians in Afghanistan, will be published in 2011.

2. This paper is based on my personal diary, on the published memoirs of the two protagonists and other publications, on published Russian documents of proceedings in the Politburo and elsewhere, and on conversations with Gorbachev's associates and some material generously supplied by them. I have mostly used the English translations of books originally in Russian where these are available. The FCO kindly gave me permission to look through relevant documents to check my recollection of the period. The papers show that the British government was very well informed about what was going on in the Soviet Union at that time. Its judgements can bear the critical eye of hindsight. Much of that insight was due to the FCO's cadre of Soviet research experts, whose contributions over many years stand out for their clarity, knowledge and wisdom.

3. Speech by Francis Pym, shadow Defence Secretary, a few weeks before the election. 


\section{FCO Views in 1979}

The FCO's Planning Staff wrote a paper for the new government which attempted to reduce these fears to more sober levels. It recognised that the Russians were likely to continue their military build-up on which their claim to superpower status chiefly rested. But their economy and agriculture were backward and inefficient, not least because of the burden of military production. Their political system was stultifying, their hold over their allies and their own national minorities was shaky, their ideology had little attraction for the outside world, and they feared the rise of China. All this weakened their effectiveness on the world scene.

There was no particular reason to think that this moderate analysis would prosper under Thatcher. But it became evident that in this field, as in many others, she was prepared to consider ideas which differed (though not by too much) from her own. She had a real intellectual curiosity, and in the four years before she met Mikhail Gorbachev, she participated in a number of seminars to broaden her knowledge and test her ideas about the Soviet Union.

\section{The FCO Seminars of 1980}

In Spring of 1980 three seminars were organised by her Private Office and the FCO Planning Staff.

The first took place on 7 February 1980. The FCO team consisted of the Foreign Secretary, Lord Peter Carrington, myself and Christopher Mallaby, who had recently returned from a stint as head of the Political Section in the embassy in Moscow. Thatcher began with a fierce monologue about the Soviet threat. But she started to listen when Christopher embarked on a brilliantly informed analysis of the economic, technological, social, and political difficulties the Soviet Union was facing, she remarked that it seemed the system was bound to collapse before long. We countered that change had begun: the Soviet Union might eventually become more democratic and less expansionist. But this would not easily happen while the Soviet Communist Party and its apparatus of repression were still intact.

There were further sessions at Chequers and in Downing Street. In the Chequers meeting, Thatcher set the FCO to compete against three academics, Michael Howard, Elie Kedourie, and Hugh Thomas. All were asked to write papers: the FCO planners wrote a paper on Soviet activities in the Third World. It was at Chequers that I first heard Thatcher develop her views on nuclear weapons as a force for peace. She remarked to me afterwards that she was not at all sure that, in the event, she could press the button: "I want grandchildren too" - an endearing flash of humanity. ${ }^{4}$

4. These seminars are described in R. BRAITHWAITE, Across the Moscow River, Yale University Press, London, 2002, pp.51-52. 
The views Thatcher expressed at these seminars showed that she was more openminded and imaginative than her reputation; and that whatever her view of the Foreign Office as an institution, she was prepared to listen to individual officials if she thought they had something useful to say.

\section{The Chequers Seminar of 1983}

In 1983 she organised another substantial seminar in Chequers. Her motive was typical: "In a cold as in a hot war it pays to know the enemy not least because at some time in the future you may have the opportunity to turn him into a friend". Once again she got everyone to write papers in advance.

Her central conclusion from the seminar was that the Western system would eventually triumph because, unlike the Soviet system, it rested on "the unique, almost limitless, creativity and vitality of individuals". But the Soviet system could only be changed by someone who had risen to power within it. "For this reason [...] I was convinced that we must seek out the most likely person in the rising generation of Soviet leaders and then cultivate and sustain him, while recognising the clear limits of our power to do so. That is why those who subsequently considered that I was led astray from my original approach to the Soviet Union because I was dazzled by $\mathrm{Mr}$ Gorbachev were wrong. I spotted him because I was searching for someone like him".

Although Thatcher wrote these words with the benefit of hindsight, they probably reflected her thoughts. She was able to test her theories during Gorbachev's visit to Britain in December 1984 and during her own visit to Moscow and Tblisi in MarchApril 1987. Each encounter marked a significant evolution in the East West relationship. ${ }^{5}$

\section{Getting to Know Gorbachev, 1984-1987}

\section{Gorbachev in London December 1984}

Gorbachev had become a candidate member of the Politburo in 1979 at the comparatively young age of 47 , and a full member a year later. His youth and energy distinguished him from the grey old men in the Politburo, some of whom had served under Stalin. British officials in Moscow and London (and some academics) saw him as a possible future leader of the Soviet Union and pressed for him to be invited to Britain so that we could get a better look at him. He was not sufficiently senior in the

5. M. THATCHER, The Downing Street Years, HarperCollins, London, 1993, pp.450-453. 
Soviet government to come on an official visit. So he came as leader of a Soviet parliamentary delegation instead.

Gorbachev's aim was to clear away obstacles to better Anglo-Soviet relations. In addition, he doubtless calculated that a successful high-profile visit to London would help in the succession struggle as it evolved in Moscow.

The centrepiece of the visit was the meeting between Thatcher and Gorbachev at Chequers. "It was not long", Thatcher later wrote,

"before the conversation turned from trivialities - for which neither Mr Gorbachev nor I had any taste - to a vigorous two-way debate. In a sense, the argument has continued ever since and is taken up whenever we meet, and as it goes to the heart of what politics is really about, I never tire of it".

Many of the themes of that first debate were taken up on many later occasions: the relative merits of the communist and the capitalist systems, the ambitions of both in the Third World, the dangers of nuclear war. Thatcher refused to allow him to divide her from President Ronald Reagan on "Star Wars", even though she had her own doubts about that project -

"one of those areas in which only a firm grasp of the scientific concepts involved allows the right policy decisions to be made. Laid back generalists from the Foreign Office - let alone the ministerial muddlers in charge of them - could not be relied upon. By contrast, I was in my element". 6

(The scientific issues were not all that complicated. Thatcher provided the willpower. But she relied heavily on the "generalists" in the Foreign Office and the Ministry of Defence to devise a policy which was both well-founded in facts and viable in politics.)

Thatcher saw immediately that Gorbachev was quite different from the traditional Soviet leader. He was not as buttoned up as Leonid Brezhnev or Andreï Gromyko nor, of course, as sinister as Josef Stalin. He had something of Nikita Khrushchev's ebullience and spontaneity. But his charm was far more polished, his grasp of the matters under discussion more sophisticated, and he seemed far less erratic. He was, in short, as Thatcher famously said, a man with whom one could do business. For his part, Gorbachev found Thatcher "self-confident, the gentle charm and feminine face disguising a rather tough and pragmatic politician".

But whatever she thought of Gorbachev personally, Thatcher was still not sure he was a man with whom one could cooperate towards long term aims. Did he simply embody the traditional aims of the Soviet Union in a more subtle, more attractive, and therefore more dangerous guise? That doubt was largely resolved when she visited Moscow in Spring 1987.

6. Ibid., p.463. 


\section{Thatcher in Moscow, March-April 1987}

She prepared for this visit with her usual relentless energy. She held another seminar, with the significant title "The Soviet System under Gorbachev: Terminal Case or Ripe for Revival?". It was already clear to Western observers that the Soviet Union was in serious trouble, and perhaps in terminal decline. Did Gorbachev really intend a fundamental change in the Soviet system? What were his prospects of success? The answers would influence the way she handled her talks with him and how the visit would be presented.

Those invited to the seminar included the Foreign Secretary Geoffrey Howe; Brian Cartledge, the Ambassador in Moscow, several other officials, and a number of distinguished academics. Thatcher was particularly impressed by the comments of one scholar, Seweryn Bialer, who believed that Gorbachev had no alternative to farreaching reform if the Soviet Union was to remain a first-rate power. Like Tito, he believed that in Communist systems you cannot have economic reforms, only political reforms with economic consequences. He would go over the heads of the managers and the bureaucrats in an attempt to mobilise the people: the political tactic which Gorbachev did indeed follow over the next three years. But the seminar's conclusions were downbeat. Fundamental change was not on the agenda. At best the Soviet Union might evolve in twenty years into something like Yugoslavia was at the time.

The British aims for the Moscow visit were sober. Thatcher hoped to become Gorbachev's principal interpreter to the West at least until normal contact was resumed between Moscow and Washington. But she was determined to be seen to be tough, while avoiding the danger of being seen as the main obstacle to detente.

Thatcher arrived in Moscow on Saturday 28 March, and spent Sunday sightseeing. Over the next two days she spent eleven hours in restricted session with Gorbachev. The exchanges were as lively as they had been in London 1984. But, this time Gorbachev, like Thatcher, was the leader of his country. "She was, as always", comments Gorbachev's diplomatic adviser Anatoliy Chernyaev, "extremely attractive, earnest but determined, stubborn, sometimes didactic. He was ironic sarcastic, at times even abrupt". Much of the conversation was about the relative merits of capitalism and communism: among other things, she told Gorbachev he did not understand economics. Each accused the other of interfering in the Third World. Thatcher raised Afghanistan. Gorbachev raised Grenada. Although he had rebutted her accusations roundly, Gorbachev later came to believe that Soviet policy towards the Third World had been excessively ideological: to a certain extent, she had been right. ${ }^{7}$

They turned to nuclear deterrence: a regular theme in all their dealings. He accused her of being prepared to accept the risk of nuclear war;

" $[s]$ he got very tense, blushed, and her expression hardened. She [...] began to talk without letting him get in a word. She poured forth the reasons why she considered it impossible

7. M. S. GORBACHEV, Memoirs, Doubleday, London, 1996, p.434. 
to give up nuclear weapons: they had been ensuring peace in Europe for forty years, they were a guarantee against a terrible war, etc. And how could he suspect her of such ghastly intentions? She became so excited that the conversation got completely out of hand. They started to interrupt each other, repeat themselves, assure one another of their best intentions". 8

It was, Gorbachev's diplomatic adviser Chernyaev thought, the most interesting of all Gorbachev's encounters with foreign politicians at that time.

But twenty years later what ordinary Russians still remembered was the interview which Thatcher gave on nationwide Soviet television on 31 March. Three Soviet journalists cross-examined her about nuclear deterrence. Unfortunately for them, she was far better briefed than they were, not only on the issues, but also on the size and capacity of the Soviet nuclear arsenal. She wiped the floor with them. Izvestia, the Soviet government newspaper, wrote that "The size of the audience - practically the whole nation - was astounding [...]. [They] showed a certain concealed satisfaction". It was "an unprecedented example of the expression of opinion in the history of Soviet TV”.

Thatcher also saw the physicist Andrei Sakharov, his wife Elena Bonner, and other former dissidents, who at that time were still supporting Gorbachev and his reforms. She told them firmly that it was not enough to support him now. They should continue to support him when the going got rough. The costs of reform would be evident long before the benefits came through. And indeed when the going got rough a few years later, the Russian liberals did withdraw their support from Gorbachev, and helped to usher in the successes, but also the great failures, of the Yeltsin regime.

As she left Moscow on 1 April, Thatcher called her trip "the most fascinating and invigorating visit I have ever made abroad as Prime Minister". It was indeed a sensational political event, even though there was no breakthrough on any matter of substance. There had been a remarkably candid and coherent exchange between the two protagonists. Their relationship had been strengthened. Thatcher now believed that the West needed perestroika to succeed as much as the Soviets. It was this new belief that Thatcher sought to convey to President Reagan and her other Western partners. She no longer worried that Gorbachev was simply the old Soviet wine in a more attractive bottle. Instead she was concerned that his reforms would fail on the opposition of the hardliners in the Soviet party, the army, and the secret police. Her concern was justified in August 1991 when Gorbachev's critics mounted a coup against him.

Gorbachev told the Politburo on 1 April that he had told Thatcher that her arguments about nuclear weapons would provide other countries with the justification for acquiring them too. She had been ambiguous about preserving the Anti-Ballistic Missile Treaty: but her argument that the march of science could not be stopped could

8. A.S. CHERNYAEV, My Six Years with Gorbachev, Pennsylvania State University Press, University Park, 2000, p.99. Chernyaev's account is closely based on the Soviet official record, and on his own diary and notes. 
equally be applied to biological and chemical weapons. He was taken aback when she said that the West was afraid of the Soviet Union. ${ }^{9}$ But her appearance on television had made a positive impression on the Soviet public. Soviet women found her sympathetic, she had not emphasised ideological differences in her public appearances, and she had undertaken to speak up for perestroika back home. That probably irritated the Americans: but he continued to keep her in touch with his dealings with them. ${ }^{10}$

\section{The two meet briefly in December 1987}

Thatcher next met Gorbachev in December 1987, when he made a brief stopover at the RAF base in Brize Norton on his way to see Reagan in Washington: the Soviet Foreign Ministry remarked in public that "London is in the middle of the road between Moscow and Washington in more ways than one". At the last minute the visit was nearly derailed by an attack on Raisa Gorbachev in the London weekly paper The Observer.

The recent sacking of Boris Yeltsin from the Politburo had dented Gorbachev's image both abroad and among liberals at home. He had lost some of his bounce, and he needed the appearance of success abroad. The short meeting between the two leaders could hardly produce much of substance. There was some discussion of arms control. Gorbachev refused to be drawn on Afghanistan, although negotiations for a Soviet withdrawal had already begun in Geneva. But the vibes were good, and Thatcher and Gorbachev had their customary set-to over lunch, this time over Lenin's historical legacy.

\section{The Go-between}

\section{Gorbachev in London April 1989}

In the spring of 1989 President Bush had just come into office, and was conducting a rigorous review of policy towards the Soviet Union. The Republican Right had accused him in the past of being too complacent about the Soviet threat. His new National Security Adviser, Brent Scowcroft, believed that Gorbachev was potentially more dangerous than his predecessors: his new foreign policy might be simply intended to throw the West off its guard while the Soviet economy was rebuilt; the

9. A.S.CHERNYAEV et al, V Politburo TsK KPSS..., Alfaprint, Moscow, 2006, p.182.

10. Ibid., pp.162-163 and 168. Gorbachev told the Politburo on 16 April that he would let Thatcher know of the exchange he had just had with Shultz on nuclear weapons. 
challenge would then be renewed. Robert Gates, Scowcroft's deputy and later Director of the CIA, said at about the same time that

"A long, competitive struggle with the Soviet Union still lies before us. [...] The dictatorship of the Communist Party remains untouched and untouchable".

Bush had called Gorbachev on the telephone and sent him a soothing letter. But as the weeks went by, and the Americans continued to refrain from substance, Gorbachev was beginning to fear the worst. ${ }^{11}$

British officials were not very happy about the proposed visit - Gorbachev's third to Britain. They worried that European public opinion was being carried away by Gorbymania. He had gained the moral high ground with his spectacular initiatives, such as his announcement at the United Nations in December of substantial cuts in the Soviet forces in Germany. He might in any case be dislodged by a coup. The briefing for the visit was appropriately wary. Officials advised that Thatcher should show support for what Gorbachev was doing at home. But she should make it clear that he needed to do much more - in the field of human rights and international affairs - before the Soviet Union could be accepted as a normal member of the international community. We would keep up our own defences meanwhile. Officials knew well enough that the main deals would be done between the Russians and the Americans. So they deliberately set out to play down public expectations.

The visit to Britain was important to Gorbachev primarily because he had so far failed to establish a personal relationship with the new American President to match the understanding he had had with Reagan. Bush was still reappraising US policy towards the Soviet Union, and the continuing silence from Washington was making Moscow nervous. Thatcher could, perhaps, provide clues as to what was going on. ${ }^{12}$

Although Gorbachev's short-term aim was to advocate his new policies, he had a longer term worry as well. Europe was forging ahead, and attracting even the members of the Warsaw Pact into its orbit. Gorbachev needed to do what he could to lessen the risk that the Soviet Union would find itself stranded on the borders of Asia.

And Gorbachev was on shaky ground at home as well. He was still digesting the results of the national elections he had organised in March. The Communist administrations of Moscow, Leningrad, and Kiev had been swept from power. One in four of the powerful Oblast Party secretaries, the Commander of the Soviet Forces in Germany, and the Military District Commanders - all hitherto sure of a seat in the Supreme Soviet - were thrown out. No nationalist or anti-Semitic candidate got elected. Nothing like this had yet happened in any other country of the Warsaw Pact. The election results, Gorbachev claimed, were a success for perestroika. But the increasingly battered Communist Party was still his main instrument of power. And all would eventually depend on the success of his economic reforms. The problems were intellectually, technically, and politically most complex. But Gorbachev had failed to take a grip. His ability to do so might well be the acid test for the future of his reforms.

11. R. BRAITHWAITE, Across ..., op.cit., p.74.

12. R. BRAITHWAITE, Diary, 1988-1992 (unpublished): entry for 20 January 1989. 
Thatcher's visit to Moscow in 1987 was still echoing among the Soviet public. She was, the embassy thought, perhaps the only leader with whom Gorbachev could discuss domestic and foreign policy on equal terms. If he could not get her to understand his domestic and foreign policies, his chances of influencing Western policy more widely would be diminished. ${ }^{13}$

Gorbachev and Thatcher met in Downing Street on 6 April. Gorbachev spoke throughout without notes or a brief. The discussion covered the standard subjects: defence, arms control, and regional problems. But the central issue was Gorbachev's concern that the Americans no longer thought it was in their interest for perestroika to succeed, and that they were worried about Gorbymania in Europe. Thatcher stoutly contradicted him: Bush would continue the same policies as his predecessor. Even so, he repeated his fear that the new American President was being hijacked by "certain circles", coded language for the reactionaries in Washington in his speeches at dinner that evening at Number 10 and at the Guildhall the following day. In an aside over dinner, he remarked to the Prime Minister that the problem of the nationalities in the Soviet Union was a nightmare. If he gave them too much autonomy they would push for independence and the post-war settlement would be undone. Thatcher urged him to strike a new balance between the centre and the nationalities: he must move forward, not back.

Gorbachev's last engagement was lunch at Windsor Castle with the Queen. Both were ill-at-ease to begin with: constrained perhaps by the ghost of the Queen's relative, the murdered Tsar Nicholas II. But they became more animated, until at some point he invited her to Russia and she accepted: she would come to Russia "in due course" ("due course" turned out to be Autumn 1994, when Yeltsin, not Gorbachev, was the beneficiary). By the end of the meal the ghost seemed to have been laid. ${ }^{14}$ Gorbachev was genuinely pleased by the warmth of his reception, both by his hosts and by the British people. He told the Politburo that he was struck by Thatcher's independence of mind and her understanding. You could talk to her about anything: nuclear weapons, Northern Ireland, the future of the Soviet Union. Bush and Kohl spoke about her ambition to become the leader of the West with a certain irony. She thought perestroika was in the interest of the West, and feared lest it be cut short. Altogether, he concluded, his contact with her was valuable. ${ }^{15}$ But for all the warmth, the British government had not expected the visit to produce anything of substance, and there had indeed been none. Thatcher's role as a go-between - essential, or perhaps only convenient - was coming to an end. Quite soon the action would pass to the Americans and the Germans, and there would be little but sentiment left. ${ }^{16}$

Business of a substantial but unproductive kind followed a few weeks later. On 19 May, Thatcher wrote to Gorbachev informing him that the British had just expelled

13. R. BRAITHWAITE, Across ..., op.cit., p.106; and Diary, entries for 29 March and 3 April 1989.

14. R. BRAITHWAITE, Across ..., op.cit., p.75.

15. Gorbachev speaking to Politburo on 1989. A.S. CHERNYAEV et al, V Politburo ..., op.cit., p.470.

16. R. BRAITHWAITE, Diary, entry for 24 April 1989; BRAITHWAITE R., Across ..., op.cit., pp. 75-76. 
thirteen Soviet officials from London on the ground that they were spies. Chernyaev, who received the letter on Gorbachev's behalf, asked two questions. Were the British sure that they had caught the right people? - to which the answer was obviously yes. And why had Thatcher not warned her good friend Gorbachev of what was in the wind during his friendly visit to London so recently? - to which there was no good answer. Gorbachev risked looking foolish and naive to his own hard men. But he reacted with sophistication and common sense. The Russians inevitably expelled thirteen Britons from Moscow in retaliation. But, as he told a British journalist, everyone had trouble with spies from time to time: the thing should not be got out of proportion. His relationship with Thatcher was unaffected. ${ }^{17}$

\section{Thatcher in Moscow, September 1989}

The Congress of People's deputies elected so sensationally in March met in an atmosphere of universal excitement. As inhibitions fell away, the deputies subjected all the sacred cows - the army, the KGB, even Gorbachev himself - to the most withering criticism. They decided that their proceedings would be televised, and for weeks on end work stopped as people throughout the country sat glued to their screens, listening to things that until a few weeks ago no sensible person had ever dared utter in public. Nothing like that had yet happened anywhere else in the Soviet bloc.

But there was soon a reaction: post congress triste. The economy was still in a mess, the miners went on strike, and the aura around Gorbachev began to fade. The unbridled Soviet press started to discuss whether a coup against Gorbachev was likely, and whether it could succeed. Soviet officials pressed for some public gesture from Thatcher to support Gorbachev and his policies. At the embassy's suggestion, Thatcher stopped in Moscow on her way from Tokyo in September. ${ }^{18}$ She arrived from Tokyo late on the evening of 22 September 1989, and spent the following morning in talks with Gorbachev. She found him relaxed and confident. Half the time, and with considerable frankness, he discussed perestroika. The implementation was proving difficult, and grave issues were being raised. The army was tense. Inflation was the main economic problem. He had strong support and he was confident he could cope with the opposition, though it would be difficult if the extremists of right and left combined against him to stir up the popular mood. In perhaps the first indication of the way his mind was to turn later, he warned that he would not exclude using "old methods" if necessary.

The rest of the discussion was on world affairs, especially arms control. Gorbachev was clearly anxious to push ahead with arms cuts at the greatest possible rate - limited no doubt by his generals' willingness to accept them.

17. Ibid., pp.62-64.

18. R. BRAITHWAITE, Diary, entry for 27 July 1989. 
There was one matter which, on Mrs Thatcher's insistence, was not written down by those taking the record of the meeting. She told Gorbachev that she was most concerned with what was happening in East Germany, which was on the verge of big changes. She wanted Gorbachev to know that Britain and Western Europe were not interested in German unification, the destabilisation of Eastern Europe or the dissolution of the Warsaw Pact. She wrongly told him that this was also the view of the President of the United States. These words may be said to mark the beginning of the end of her role as a reliable intermediary between Gorbachev and the outside world. ${ }^{19}$

In her interview with Moscow TV that afternoon, Thatcher did her best to give Gorbachev the puff she thought he needed. He

"is in extremely good form, strong, bold, vigorous, determined to carry through this great historic mission to its great conclusion. The old system that you had for seventy years produced neither personal liberty not personal prosperity. It could not and so now things are being changed [...]. We look forward to the Soviet Union becoming as well as a great military power a great international power, a great and strong economic power".

Some of her Russian listeners were irritated at the lecturing tone, while some of her own entourage thought she had gone overboard, and risked being derided in the British press after all the stout words on defence she had only just uttered in Tokyo. ${ }^{20}$

By now the Americans and the Russians were in close communication. They had resumed negotiations on arms control were proceeding. The relationship was cemented when Bush met Gorbachev in Malta in November.

In November the Berlin Wall came down. A baffled and worried Gorbachev, bereft of any coherent policy, sent a message to Thatcher on 10 November, expressing his concern about the potential for instability and violence. She replied that she too was worried that things could get out of hand. The West should do nothing to undermine Gorbachev. German reunification was not an immediate issue. The Warsaw Pact and NATO should continue to guarantee European stability. She made similar points in public in Washington at the end of the month and to NATO in December. ${ }^{21}$ As pressure grew in the winter of 1989-1990 for the early reunification of Germany, Thatcher's hostility towards it deepened and became more futile. Gorbachev still hoped to exploit her doubts to his own advantage in the negotiations on reunification. ${ }^{22}$ But Soviet officials said that the Russians were not going to snatch the chestnuts out of the fire for the French and the British just because they didn't like the prospect of Germany dominating the European Community. ${ }^{23}$

19. Record of meeting by Anatoli Chernyaev, published by National Security Archive, translated by S. SAVRANSKAYA. At http://www.gwu.edu/ nsarchiv/NSAEBB/NSAEBB293/doc03.pdf.

20. R. BRAITHWAITE, Diary, entry for 23 September 1989.

21. See The Times, 25.11.1989 and 05.12.1989.

22. A.S. CHERNYAEV et al, V Politburo ..., op.cit., pp.554 and 562.

23. R. BRAITHWAITE, Diary, entry for 19 December 1989. 
By January 1990, Thatcher had accepted with her mind that reunification was inevitable. But her heart was not in it. Shortly thereafter she organised another seminar, this time on Germany. The record gave the impression that Germany was still a threat to the stability of Europe. It leaked, and was denounced by some of the participants as biased and inaccurate. Her credibility took a further dent. ${ }^{24}$ Thatcher's role as a go-between was over and she had lost much of her international influence. She never seems to have understood that: "[I]n those last months and weeks of my premiership, while domestic political pressures mounted", she later wrote,

"I found myself once more at the centre of international events with renewed ability to influence them in Britain's interests and in accord with my beliefs". 25

\section{Thatcher bows out}

By now Gorbachev's power was visibly shrinking, undermined by the rise of Yeltsin, the grossly misjudged launch of yet another plan for a market economy, and the increase of nationalism in the Soviet republics. Thatcher's power was declining, too, as she faced a leadership challenge, economic troubles, and a more confident Labour opposition. They remained in touch: ironically, foreign affairs had become more attractive to both than the grind of domestic politics. ${ }^{26}$

\section{Thatcher's last official visit to Moscow, June 1990}

She paid her final official visit to the Soviet Union from 7-9 June 1990. She spent two hours with Gorbachev, alone except for aides. Over lunch she told him that he needed a better definition of the relative powers of central and local government, and better central government machinery. We had, she said, lots of experience of advising Indians and Africans on things like that, and she offered to help the Russians too. ${ }^{27}$

Her last official exchange with Gorbachev took place in Paris in November 1990, in the margins of the Summit which adopted the "Charter of Paris for a New Europe". That was where she heard that the ballot for the leadership of the Conservative Party had gone against her. It was the death knell of her Prime Ministership. Gorbachev was shocked at the news.

24. M. THATCHER, The Downing Street Years, op.cit., p.813.

25. Ibid., p. 770 .

26. US Embassy London, Telegram no 798 of 11 April 1990 to Washington. Text on Thatcher Foundation website.

27. R. BRAITHWAITE, Diary, entry for 8 June 1990. 


\section{Thatcher visits Moscow privately: May 1991}

In May 1991 Thatcher made one more visit to Moscow while Gorbachev was still in office. He generously gave her a private talk and a dinner, and was grateful when she told him of her support for a generous approach by the West at the forthcoming G7 Summit in London towards the Soviet Union's economic problems.

"It would be truly a tragedy if your efforts should end in failure merely because the West proved incapable of coming to your assistance in a timely fashion. Future generations will never forgive us for that". ${ }^{28}$

She met her old friends the generals among others, and she delivered a brilliant and optimistic speech to the students at the State Institute of International Relations on the theme that Russia would become prosperous if it adopted democracy and the rule of law. But without the trappings of power, she was of course diminished.

\section{CONCLUSION}

The relationship between Margaret Thatcher and Mikhail Gorbachev was one of the most colourful and dramatic political relationships of recent times. Both were highly intelligent, forceful personalities. Both loved a good argument. Each enjoyed the other's company: it was not exactly a flirtatious relationship, but an element of flirtation was there.

Notwithstanding her opposition towards everything the Soviet Union stood for, it was Thatcher who first among Western leaders scented the wind of change. She did not believe that the Soviet system could survive for ever. Her belief that it could only be challenged by an insider was vindicated by the rise of Gorbachev. Once she had concluded that Gorbachev genuinely intended to change the Soviet Union, she stuck to her view that perestroika was in the interest of the West as well as the Soviet Union. She was always prepared to say so in public, even though in private she was fully aware that perestroika could fail. Sceptics in London and Washington, many of whom predicted that the Soviet Union would still be the main threat to our security twenty years on, thought she was naïve. There is nothing in her record to justify that.

She had little illusion on the substance of her role. She accepted that her meetings with Gorbachev would achieve no breakthroughs. She was never a principal in the central negotiations on East-West relations which took place in the last years of her power. On arms control, she was able to tweak or modify American policy, but only at the margins. Her refusal to accept the realities of the German problem fatally undermined her influence with her friends.

28. M.S. GORBACHEV, Memoirs, op.cit., p.610. 
Gorbachev appreciated the public support she gave him, especially when he was in trouble at home. She was a useful indicator of changes in mood in Washington when his channels of communication with the Americans were clogged: the impressions she passed on to Washington, he believed, helped to improve relations between the United States and the Soviet Union. ${ }^{29} \mathrm{He}$ "was always more sincere with her than with others, partly because he knew that she was watching us closely and that he couldn't put anything over on her". ${ }^{30}$

From time to time she irritated him - though he tried not to show it - with her rumbustious attacks on his political beliefs. ${ }^{31}$ Her tough methods and her "inherent authoritarianism" were sometimes hard to take. He

"had the impression that in order to work with her, you had to accept her style and character unconditionally. [She] was not an easy partner for us, and her fierce anti-Communism would often hinder her from taking a more realistic view on various issues. Still one must admit that in a number of cases, she was able to substantiate her charges with facts, which eventually led us to review and criticise some of our own approaches. [... S] he was always very considerate and courteous. We eventually came to know each other better and she showed genuine warmth towards both me and Raisa Maximovna [Gorbachev]". ${ }^{32}$

He summed it up to John Major when they met in March 1991:

"We managed to build a very good relationship, which enable us to discuss the whole range of problems. It was a unique dialogue. Sometimes our exchanges could be quite sharp. But I am grateful to Margaret Thatcher for her contribution to the development not only of good Anglo-Soviet relations, but of a new type of relationship in Europe". ${ }^{33}$

29. Ibid., pp.497 and 499 .

30. A.S. CHERNYAEV, V Politburo ..., op.cit., p.230.

31. R. BRAITHWAITE, Diary, entry for 24 April 1989; R. BRAITHWAITE, Across ..., op.cit., pp. 75-76.

32. M.S. GORBACHEV, Memoirs, op.cit., p.547.

33. Extract from record of meeting between Major and Gorbachev, Moscow, 5 March 1991, supplied by A. Chernyaev. 


\title{
Political and Personal: \\ Gorbachev, Thatcher and the End of the Cold War
}

\author{
Witness Remarks
}

Andrei GRACHEV

The "special relationship" between Mikhail Gorbachev and Margaret Thatcher undoubtedly played an essential role in the process of rapprochement and the building of understanding between the new Soviet leadership and the leaders of the major Western powers. During the years of perestroika this singular mix of politics and personal chemistry originally came about as one of those accidents of history. The British Prime Minister was the only a major Western leader who had the chance to meet this untypical future Soviet General Secretary before he was elected officially to that post; a representative of the new political generation, it was still by no means certain that he would be chosen. ${ }^{1}$

For Gorbachev, it really was only by chance in late 1984 that Thatcher became his first top-level Western contact. Having succeeded Mikhail Suslov as chief ideologist of the Politburo, he also inherited the role of Chairman of the Supreme Soviet Foreign Affairs Committee. It was largely accidental that this should have meant that he would lead a Supreme Soviet delegation to Britain. However, for Thatcher it was rather different. She was curious about Gorbachev and keen to meet him. Her interest had been aroused some time before, probably at the noted Chequers seminar on 8 September 1983 where Archie Brown pointed to him as a future General Secretary, describing him as an unusual Soviet political figure and certainly the most promising.

According to the memoirs of Anatoly Chernyaev, who became Gorbachev's principal assistant for international affairs (he remains the main source of first-hand information about the development of this political "romance"), the story of the visit started quite prosaically at the end of September 1984. Chernyaev, who at that time was deputy head of the International Department of the Central Committee and responsible for contacts with British left-wing political parties, recalls that after he had accompanied Gorbachev to a meeting with a delegation of the British Communist

1. Andrei Grachev is a Russian political analyst and journalist, $\mathrm{Ph} . \mathrm{D}$ in history from the Academy of Social Sciences, Moscow (1976), presently editorialist for the Novaya Gazeta (Russia) and Chairman of the Scientific Committee of The World Political Forum. Grachev was Consultant and Deputy Director on the International Department of the Central Committee of CPSU (1974-1987), adviser and official Spokesman for Mikhail Gorbachev until his resignation in December 1991 and senior research fellow in the Institute of World Economy and International relations, Russian Academy of Science (Moscow) between 1992-1995. Grachev held positions of Visiting Professor in Kyoto and Paris and of Senior Researcher in Oxford. Among his books in Russian, French and English: L'Histoire vraie de la fin de l'URSS (1992); La chute du Kremlin. L'empire du non-sens (1994); Meeting of Civilizations: Clash or Dialogue?, UNESCO (1996); Le mystère Gorbatchev. La terre et le destin (2004); Gorbachev's Gamble. Soviet Foreign Policy and the End of Cold War (2008.). 